\title{
Comparative morphology of gonads from six species of fish belonging to the family Anostomidae (Characiformes: Anostomidae)
}

\author{
Fábio Pereira Arantes ${ }^{1}$, Fabiano Andrade Silva ${ }^{1}$, José Enemir dos Santos ${ }^{1}$, \\ Elizete Rizzo ${ }^{2}$ Yoshimi Sato $^{3} \&$ Nilo Bazzoli ${ }^{*}$ \\ 1. Programa de Pós-Graduação em Zoologia de Vertebrados, Pontifícia Universidade Católica de Minas Gerais, PUC \\ Minas, Belo Horizonte, Minas Gerais (MG), 30535-610, Brasil; fparantes@gmail.com, zoologia@pucminas.br, \\ enemir@pucminas.br, bazzoli@pucminas.br \\ 2. Laboratório de Ictiohistologia, Departamento de Morfologia, Universidade Federal de Minas Gerais (UFMG), C.P. \\ 486, Minas Gerais, 30161-970, Brasil; ictio@mono.icb.ufmg.br \\ 3. Centro Integrado de Recursos Pesqueiros e Aquicultura de Três Marias (CODEVASF), 39205-000 Três Marias, Minas \\ Gerais Brasil; sato.codevasf@gmail.com \\ * Correspondence
}

Received 27-X-2016. Corrected 06-II-2017. Accepted 03-III-2017.

\begin{abstract}
In fishes, gonad morphology is an important parameter to understand the reproductive biology, phylogenetic relationships and systematic studies. The main objective of this study was to make a comparative analysis of the morphology of mature ovary and testis in six fish species of the family Anostomidae. A total of 212 specimens, presenting maturing gonads, were captured from the São Francisco River, Três Marias Reservoir area, in Southeastern Brazil, between August 2008 and December 2010. The six analyzed species had mature ovaries and showed a grayish color. In vitellogenic oocytes (VO), cortical alveoli (CA) were composed by small vesicles in all Leporinus species, but in Leporellus vittatus and Schizodon knerii the CA were large vesicles. However, the CA of all species showed similar histochemical content. The pellucid zone consists of two layers to all species, but it was thicker in $S$. knerii $(11.5 \pm 1.8 \mu \mathrm{m})$ than in L. vittatus $(9.0 \pm 0.8 \mu \mathrm{m})$ and Leporinus species $(3.5 \pm 0.6-8.7 \pm 0.9 \mu \mathrm{m})$. Follicular cells of the VO were respectively cubic and prismatic in animal and vegetative poles of $S$. knerii $(22.3 \pm 3.2$ and $61.1 \pm 9.6 \mu \mathrm{m})$, and squamous in the other species $(1.3 \pm 0.3-1.6 \pm$ $0.3 \mu \mathrm{m})$. Females of $S$. knerii and males of $L$. vittatus showed lower values of gonadosomatic index (GSI) than the other assessed species. All evaluated species presented testicular morphology similar to most neotropical Characiformes, with unrestricted spermatogonial testis and anastomosing tubular organization of seminiferous tubules. Phenotypical differences in the vitellogenic oocyte of Anostomidae fishes, confirmed the taxonomic position of S. knerii as different genus in relation to Leporinus and L. vittatus. Despite being placed in different genera, the characteristics of the vitellogenic oocytes of $L$. vittatus were similar to those found in the studied Leporinus. Rev. Biol. Trop. 65 (2): 713-723. Epub 2017 June 01.
\end{abstract}

Key words: ovary, testis, follicular cells, freshwater fish, histology.

Despite the fact that gonad morphology is extensively used for the understanding of reproduction and life story of the species, few studies compare reproductive parameters between related species, because these characteristics may be phenotypically similar in some groups (Godinho, Lamas, \& Godinho, 2010). Gonad morphology has been used for the understanding of the reproduction and the phylogenetic relationships amongst fishes (Belova, 2008; Martins et al., 2011; Melo et al., 2011). Although some studies showed that species of the same family and sub-family usually present a common pattern of gonad morphology (Rizzo, Sato, Barreto, \& Godinho, 2002; Martins et al., 2011; Melo et al., 2011), in specialized literature there are no studies comparing the gonad morphology of the Anostomidae 
family. In a review, Parenti and Grier (2004) observed an evolutionary net on the teleosts testis morphology, through the organization of the seminiferous tubules and the distribution of spermatogonia throughout the germinal epithelium. In the Apogonidae family, some characteristics are common amongst closely related genera and species, contributing to the understanding of the evolutionary reproductive history of this group (Fishelson \& Gon, 2008).

The Characiformes are one of the orders with the largest number of families and subfamilies amongst fish (Nelson, 2006), and the Anostomidae family comprises approximately 163 species in 12 genera distributed throughout the neotropical region (Garavello \& Britski, 2003; Reis, Kullander, \& Ferraris, 2003). In the São Francisco River basin, one of the main rivers in Brazil for fishing resources, there are three genera of Anostomidae, Leporellus Lütken 1875, Leporinus Agassiz 1829 and Schizodon Agassiz 1829, including the commercially important species for sport and small-scale fishing of Leporinus obtusidens (Valenciennes 1837), which may reach a length of $40 \mathrm{~cm}$ (Garavello \& Britski, 2003).

Since gonad morphology is an important parameter for the understanding of the reproductive biology, phylogenetic relationships and systematic studies, the main objective of this study is to make a comparatively analysis of the morphology of mature ovary and testis in six fish species of the family Anostomidae of the São Francisco River basin, in Minas Gerais, Brazil: Leporellus vittatus (Valenciennes 1850);
Leporinus obtusidens; Leporinus piau Fowler, 1941; Leporinus reinhardti Lütken, 1875; Leporinus taeniatus Lütken, 1875 and Schizodon knerii (Steindachner 1875).

\section{MATERIALS AND METHODS}

A total of 212 specimens of six Anostomidae (Table 1), presenting maturing gonads (Fig. 1), were captured from São Francisco River, Três Marias Reservoir area $\left(918^{\circ} 15^{\prime} \mathrm{S}\right.$ - 45 $21^{\prime} \mathrm{W}$ ), in Southeastern Brazil, between August 2008 and December 2010. The fish were captured using gillnets with meshes of $3,4,5,6,7$ and $8 \mathrm{~cm}$ between opposite knots. The fish, which were still alive in the nets, were handled in accordance with the Animal Experimentation Guidelines established by the Brazilian College of Animal Experimentation (COBEA) and were euthanized by transversal section of the medulla (Andersen et al., 2008). After capture, the fish were cooled and transported to the laboratory in ice boxes. In the laboratory, total length (TL) was taken with an ichthyometer of $100 \mathrm{~cm}$, and body weight (BW) were recorded using a digital centesimal scale. After dissection, gonads were photographed, analyzed and anatomically characterized, being their form and color recorded. The gonad weight $(\mathrm{GW})$ was also determined in order to calculate the gonadosomatic index (GSI): GSI $=\mathrm{GW} \times 100 / \mathrm{BW}$. Anatomical terminology and methods follows Bazzoli (2003).

For microscopic analysis, gonad fragments were fixed in Bouin's fluid for 12 hours

TABLE 1

Total length (TL) and body weight (BW) of six species of Anostomidae from the São Francisco River basin, Minas Gerais, Brazil

\begin{tabular}{lcccccc}
\multicolumn{1}{r}{ Species } & \multicolumn{2}{c}{ TL $(\mathrm{cm})$} & \multicolumn{2}{c}{ BW $(\mathrm{g})$} & \multicolumn{2}{c}{ N } \\
& Males & Females & Males & Females & Males & Females \\
L. reinhardti & $18.7 \pm 2.2$ & $23.4 \pm 2.5$ & $87.3 \pm 33.5$ & $201.6 \pm 68.9$ & 17 & 38 \\
L. piau & $21.4 \pm 2.9$ & $24.0 \pm 3.3$ & $171.5 \pm 77.4$ & $209.7 \pm 75.0$ & 11 & 26 \\
L. obtusidens & $32.2 \pm 10.7$ & $40.9 \pm 12.3$ & $550.0 \pm 644.7$ & $1255.1 \pm 1118.8$ & 14 & 15 \\
L. taeniatus & $16.1 \pm 2.0$ & $19.9 \pm 2.9$ & $48.1 \pm 23.7$ & $112.6 \pm 58.4$ & 17 & 23 \\
L. vittatus & $17.3 \pm 1.1$ & $18.2 \pm 3.6$ & $56.6 \pm 9.4$ & $76.7 \pm 46.7$ & 09 & 13 \\
S. knerii & $26.7 \pm 3.0$ & $31.0 \pm 4.6$ & $242.7 \pm 79.3$ & $388.3 \pm 141.3$ & 12 & 17 \\
\hline
\end{tabular}



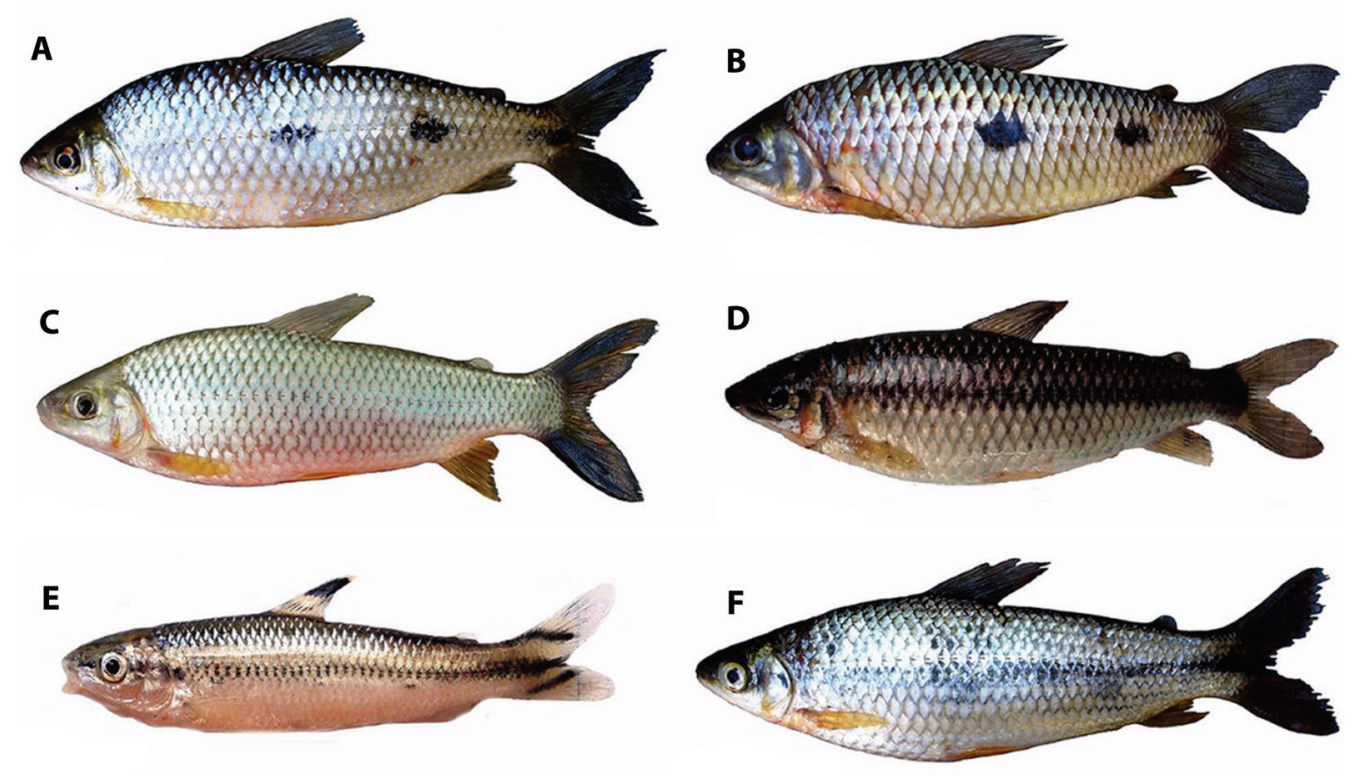

Fig. 1. A. Leporinus reinhardti. B. Leporinus piau. C. Leporinus obtusidens. D. Leporinus taeniatus. E. Leporellus vittatus. F. Schizodon knerii. Scale bars: A, $1.7 \mathrm{~cm} ; \mathrm{B}, 1.8 \mathrm{~cm} ; \mathrm{C}, 2.7 \mathrm{~cm} ; \mathrm{D}, 1.6 \mathrm{~cm} ; \mathrm{E}, 1.5 \mathrm{~cm}$ and F, $2.4 \mathrm{~cm}$.

and then were submitted to routine histological techniques [i.e. paraffin embedding, 3 to $5 \mu \mathrm{m}$ thick microtome sections, hematoxylin-eosin and Gomori Trichrome staining (HE)].

To determine the histochemical content of the oocyte structures, the following techniques were used as follows (Pearse, 1985): periodic acid Schiff (PAS) for neutral glycoproteins and sialomucins; Alcian blue $\mathrm{pH} 2.5(\mathrm{AB} \mathrm{pH} 2.5)$; Alcian blue $\mathrm{pH} 0.5$ (AB pH 0.5); Acidic hydrolysis with $\mathrm{HCl} 0.1 \mathrm{~N}\left(8 \mathrm{~h}\right.$ at $\left.60^{\circ} \mathrm{C}\right)$ to extract sialic acid, followed by PAS and Alcian blue $\mathrm{pH} 2.5$.

The determination of oocyte development stages and the gonad maturation stages was carried out according Bazzoli (2003). For morphological analyses, i.e., diameter of vitellogenic oocytes, the pellucid zone thickness and the follicular cell height, we selected 50 undamaged oocytes without retraction and with cuts crossing the nucleus for each of the studied species. The morphometry was performed under a light microscope coupled to a 5.0 megapixel digital camera and computer using the Motic Images Plus 2.0 image analyzer software.

Measurements were conducted with a micrometric ocular connected to a light microscope. In order to compare the histometric measures and the GSI among the species analyzed, a Kruskal-Wallis test followed by a Dunn test with $\mathrm{p} \leq 0.05$ were performed.

\section{RESULTS}

Among the species analyzed, L. obtusidens was largest in total length and body weight, while the smallest were $L$. taeniatus and $L$. vittatus (Table 1).

Ovaries of the Leporinus, Leporellus and Schizodon were paired, elongated, fusiform, placed dorsally-laterally to the gas bladder and the coelomic cavity and dorsally to the digestive tube. Mature ovaries were grayish, however vary in hues depending on the species (Fig. 2A and Fig. 3A). For mature females, GSI was significantly smaller in $S$. knerii (Table 2). 

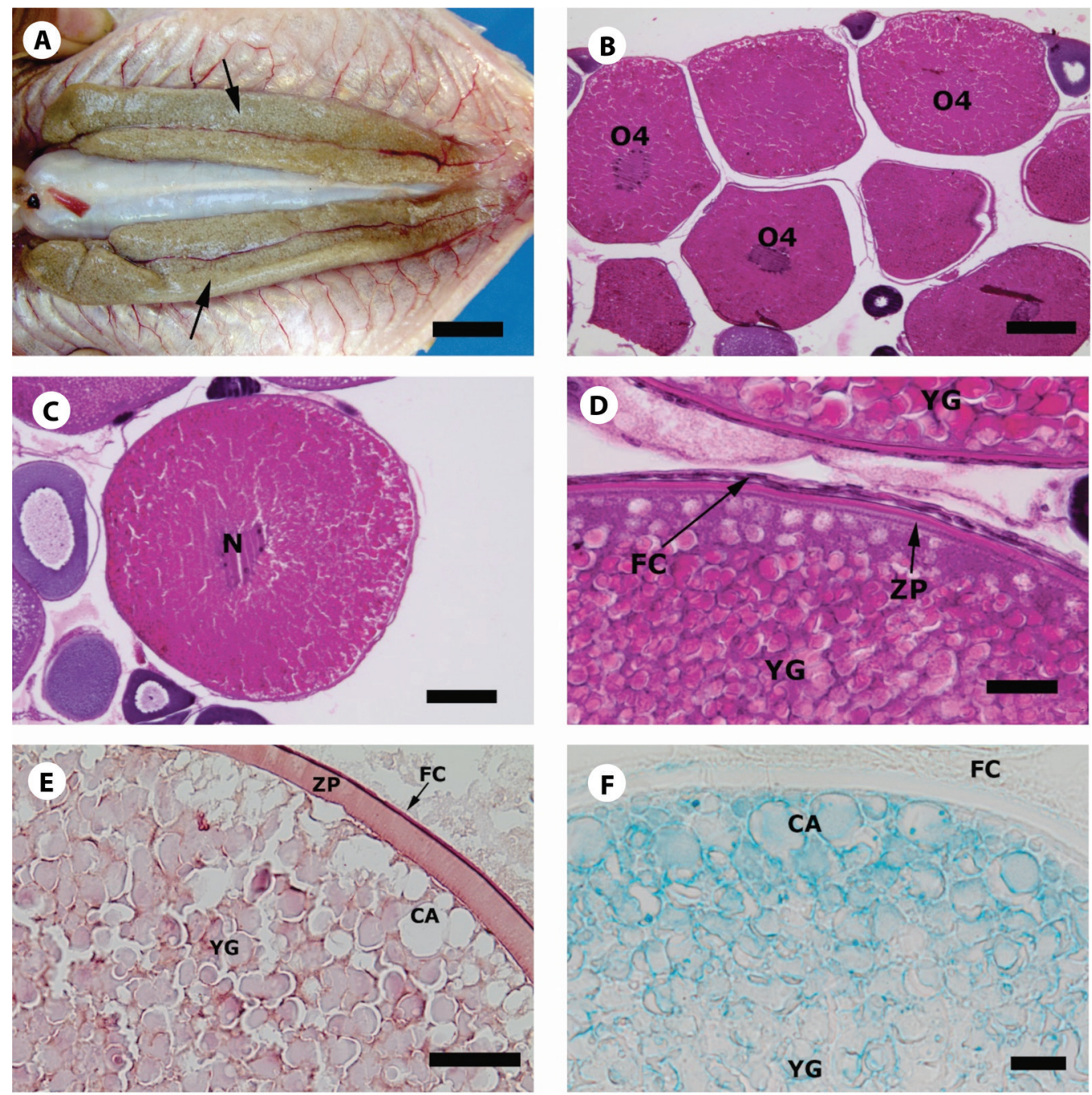

Fig. 2. Mature ovaries and vitellogenic oocytes of Anostomidae fishes. A. Macroscopic view of L. obtusidens ovaries (arrows). B. Microscopic view of $L$. reinhardti ovaries filled with vitellogenic oocytes (O4) - HE. C. Detail of vitellogenic oocytes of $L$. reinhardti. HE. D. Squamous follicular cells in vitellogenic oocytes of $L$. vittatus. HE. E. Positive reaction to PAS in oocyte structures of L. piau. F. Positive reaction to Alcian blue pH 2.5 in the cortical alveoli and follicular cells of L. piau. N, Nucleus; FC, Follicular cells; ZP, Pellucid zone; CA, Cortical alveoli; YG, Yolk globules. Scale bars: A, $5.7 \mathrm{~cm}$; B, $200 \mu \mathrm{m}$; C, $160 \mu \mathrm{m}$; D, $20 \mu \mathrm{m}$; E, $20 \mu \mathrm{m}$; F, $20 \mu \mathrm{m}$.

The ovaries of the analyzed fish were covered by the tunica albuginea, which emits septa towards the lumen forming the ovigerous lamellae, where there were nests of oogonia and oocytes at different stages of development. The ovaries were linked caudally forming the ovarian duct that communicates with the urogenital papilla.
Histologically, mature ovaries of the analyzed fishes were filled with vitellogenic oocytes with diameters varying between 586.7 \pm 26.5 and $616.6 \pm 59.4 \mu \mathrm{m}$ (Fig. $2 \mathrm{~B}$ and Table 2 ), with the ooplasm filled with acidophilus spheric yolk globules (Figs. 2C and Fig. 3B) and cortical alveoli in the peripheral ooplasm (Fig. 2F and Fig. 3F). In all species analyzed, 

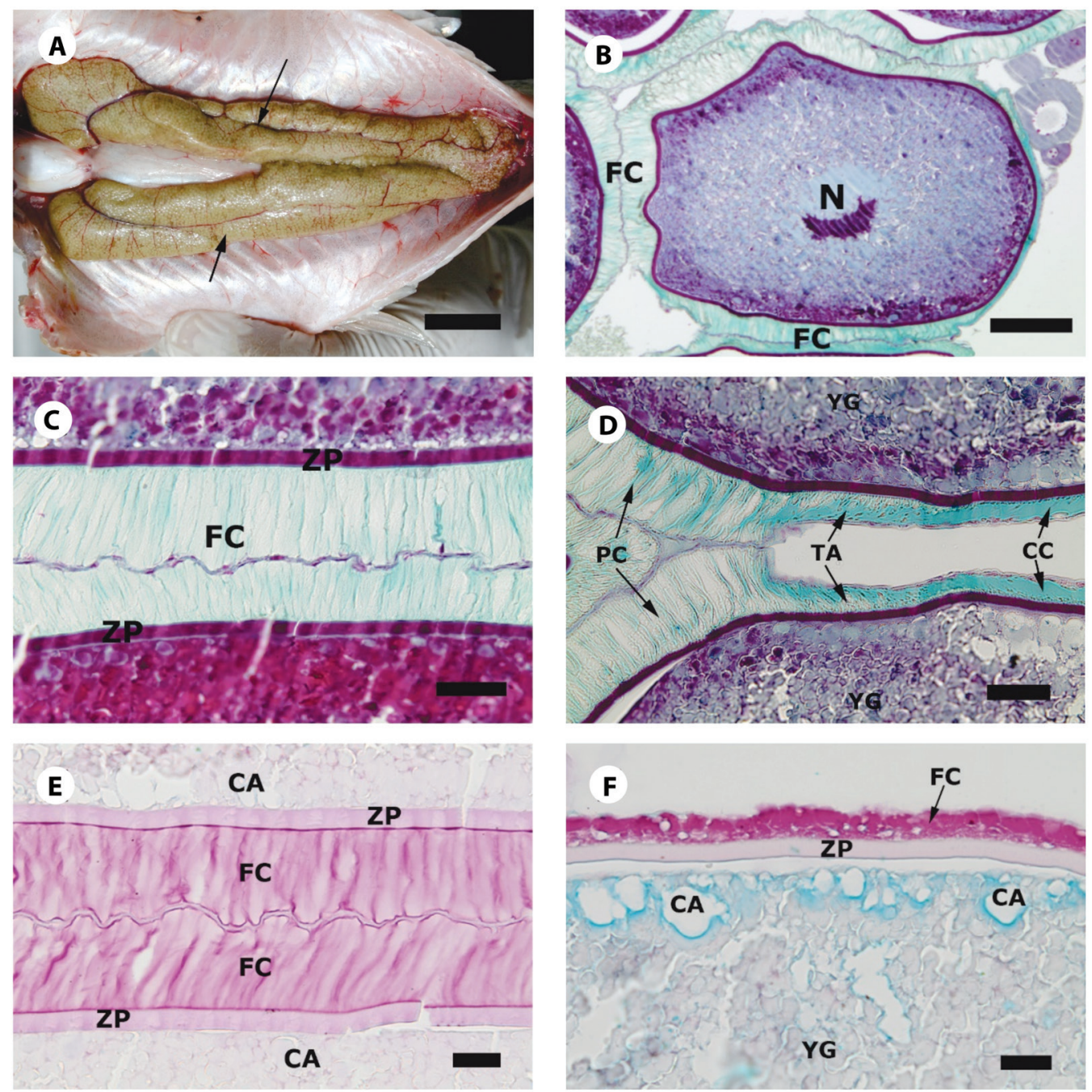

Fig. 3. Schizodon knerii's ovaries. A. Macroscopic view of mature ovaries (arrows). B. Vitellogenic oocytes. Gomori Trichrome. C. Details of the prismatic follicular cells in the vegetative pole. Gomori Trichrome. D. Transition between cubic follicular cells in the animal pole and prismatic follicular cells in the vegetative pole. Gomori Trichrome. E. Positive reaction to PAS in oocyte structures. F. Positive reaction to Alcian Blue $\mathrm{pH} 2.5$ in the cortical alveoli and to PAS in the follicular cells, pellucid zone and yolk globule. N, Nucleus; FC, Follicular cells; ZP, Pellucid zone; CA, Cortical alveoli; YG, Yolk globules; TA, Transition area. Scale bars: A, $4.5 \mathrm{~cm}$; B, $100 \mu \mathrm{m}$; C, 35 $\mu \mathrm{m}$; D, $27 \mu \mathrm{m}$; E, $20 \mu \mathrm{m}$; F, $20 \mu \mathrm{m}$.

the pellucid zone consists of two layers with a thickness, in the vitellogenic oocytes, varying between $3.5 \pm 0.6$ and $11.5 \pm 1.8 \mu \mathrm{m}$, and were significantly thicker in S. knerii (Table 2). The follicular cells of Leporinus species and $L$. vittatus were squamous with heights varying between $1.3 \pm 0.3$ and $1.6 \pm 0.3 \mu \mathrm{m}$ (Fig. 2D and Table 2), whereas for $S$. knerii, they were prismatic in the vegetative pole, with heights of $61.1 \pm 9.6 \mu \mathrm{m}$ (Fig. 3C and Table 2) and cubic in the animal pole, with heights of $22.3 \pm$ $3.2 \mu \mathrm{m}$ (Fig. 3D).

Neutral glycoproteins were detected in the follicular cells, pellucid zone, cortical alveoli and yolk globules of the six species studied due to the positive reaction to the PAS technique 
TABLE 2

Gonadosomatic Index (GSI) and oocyte diameter (DO), cortical alveoli's vesicles diameter (CA), pellucid zone thickness (ZP) and follicular cells height (FC) of vitellogenic oocytes of six species of Anostomidae from the São Francisco River basin, Minas Gerais, Brazil

\begin{tabular}{lcccccc}
\multicolumn{1}{c}{ Species } & \multicolumn{2}{c}{ GSI } & \multicolumn{2}{c}{ Structure } \\
& Males & Females & DO $(\mu \mathrm{m})$ & CA $(\mu \mathrm{m})$ & ZP $(\mu \mathrm{m})$ & FC $(\mu \mathrm{m})$ \\
L. reinhardti & $1.2 \pm 0.2^{\mathrm{a}, \mathrm{b}}$ & $18.7 \pm 1.9^{\mathrm{a}}$ & $586.9 \pm 34.0^{\mathrm{a}}$ & $9.8 \pm 2.8^{\mathrm{a}}$ & $3.5 \pm 0.6^{\mathrm{a}}$ & $1.4 \pm 0.3^{\mathrm{a}}$ \\
L. piau & $2.7 \pm 1.5^{\mathrm{b}}$ & $15.8 \pm 1.7^{\mathrm{a}}$ & $616.6 \pm 59.4^{\mathrm{a}}$ & $10.0 \pm 2.4^{\mathrm{a}}$ & $8.3 \pm 0.7^{\mathrm{b}}$ & $1.3 \pm 0.3^{\mathrm{a}}$ \\
L. obtusidens & $1.1 \pm 0.3^{\mathrm{a}, \mathrm{b}}$ & $18.7 \pm 1.6^{\mathrm{a}}$ & $586.7 \pm 26.5^{\mathrm{a}}$ & $10.5 \pm 2.3^{\mathrm{a}}$ & $8.7 \pm 0.9^{\mathrm{b}}$ & $1.6 \pm 0.3^{\mathrm{a}}$ \\
L. taeniatus & $1.7 \pm 1.6^{\mathrm{a}, \mathrm{b}}$ & $17.7 \pm 1.3^{\mathrm{a}}$ & $600.6 \pm 24.5^{\mathrm{a}}$ & $10.3 \pm 2.2^{\mathrm{a}}$ & $8.1 \pm 1.1^{\mathrm{b}}$ & $1.5 \pm 0.3^{\mathrm{a}}$ \\
L. vittatus & $0.4 \pm 0.1^{\mathrm{c}}$ & $17.9 \pm 0.5^{\mathrm{a}}$ & $601.4 \pm 82.4^{\mathrm{a}}$ & $8.8 \pm 2.1^{\mathrm{a}}$ & $9.0 \pm 0.8^{\mathrm{b}}$ & $1.3 \pm 0.4^{\mathrm{a}}$ \\
S. knerii $^{\mathrm{a}}$ & $1.0 \pm 0.7^{\mathrm{a}}$ & $12.7 \pm 1.2^{\mathrm{b}}$ & $582.8 \pm 30.1^{\mathrm{a}}$ & $20.3 \pm 3.4^{\mathrm{b}}$ & $11.5 \pm 1.8^{\mathrm{c}}$ & $22.3 \pm 3.2^{\mathrm{b}+}$ \\
\hline
\end{tabular}

Kruskal-Wallis Test followed by Dunn Test. Different letters $=\mathrm{p} \leq 0.05 .+$ animal pole, ${ }^{*}$ vegetative pole.

(Fig. 2E and Fig. 3E). Glyco-conjugated carboxylic acids were detected in the follicular cells of the Leporinus species and L. vittatus (Fig. 2F) and in the cortical alveoli of all species studied due to the positive reaction to $\mathrm{AB}$ pH 2.5 (Fig. 2F and Fig. 3F), negative to AB $\mathrm{pH} 0.5$ and unaltered reaction to PAS and $\mathrm{AB}$ pH 2.5 after acidic hydrolysis.

The testis of the Leporinus species, $L$. vittatus and $S$. knerii were even, elongated, fusiform, placed dorsally-laterally to the gas bladder and the coelomic cavity, and dorsally to the digestive tube. There were no testicular accessory structures in the analyzed species. The mature testes were milky-white in color (Fig. 4A) and are histologically constituted of seminiferous tubules which contain spermatogenic cells (Fig. 4B). The wall of the cysts is formed by cytoplasmic extensions of the Sertoli cells and in each cyst the germinative cells were in the same developmental stage (Fig. 4C). In the testis of the Leporinus, L. vittatus and S. knerii, spermatogonia were distributed throughout the seminiferous tubules, which were connected forming anastomosis (Fig. 4D), which converge to the spermatic duct.

\section{DISCUSSION}

Differences in diameter of vitellogenic oocytes may occur between species and populations of the same species due to variations in gene expression (Patiño \& Sullivan, 2002; Kolm \& Ahnesjö, 2005). Furthermore, sedentary neotropical freshwater fish species usually have larger adhesive eggs, while migratory neotropical freshwater fish species have relatively small free eggs (Rizzo et al., 2002; Melo et al., 2011). In contrast, amongst the Anostomidae analyzed in this study, only $S$. knerii has adhesive eggs (Rizzo et al., 2002). In the present study, although some significant differences in vitellogenic oocytes of the analyzed species were observed, macroscopic and microscopic similarities in gonadal morphology were also registered. According to Balon (1990), throughout the evolution process, new environments were able to be exploited, once the embryonic development can be accelerated by yolk volume increase, with the consequent increase in oocyte diameter that enables to produce largest young when the first feeding exogenous occurs. Also, according to Balon (1990) on the evolution of reproductive patterns, the survival of the young is favored by increasing endogenous food supply, because in the evolutionary sequence, the behavior to spread gametes and produce largest young increases its chances of survival. The reproductive strategy characterized by pelagic and small eggs, poor in nutrients and pronounced larval period seems to be ancestor, being in agreement with the most plausible theory about the origin of vertebrates (Balon, 1975). 

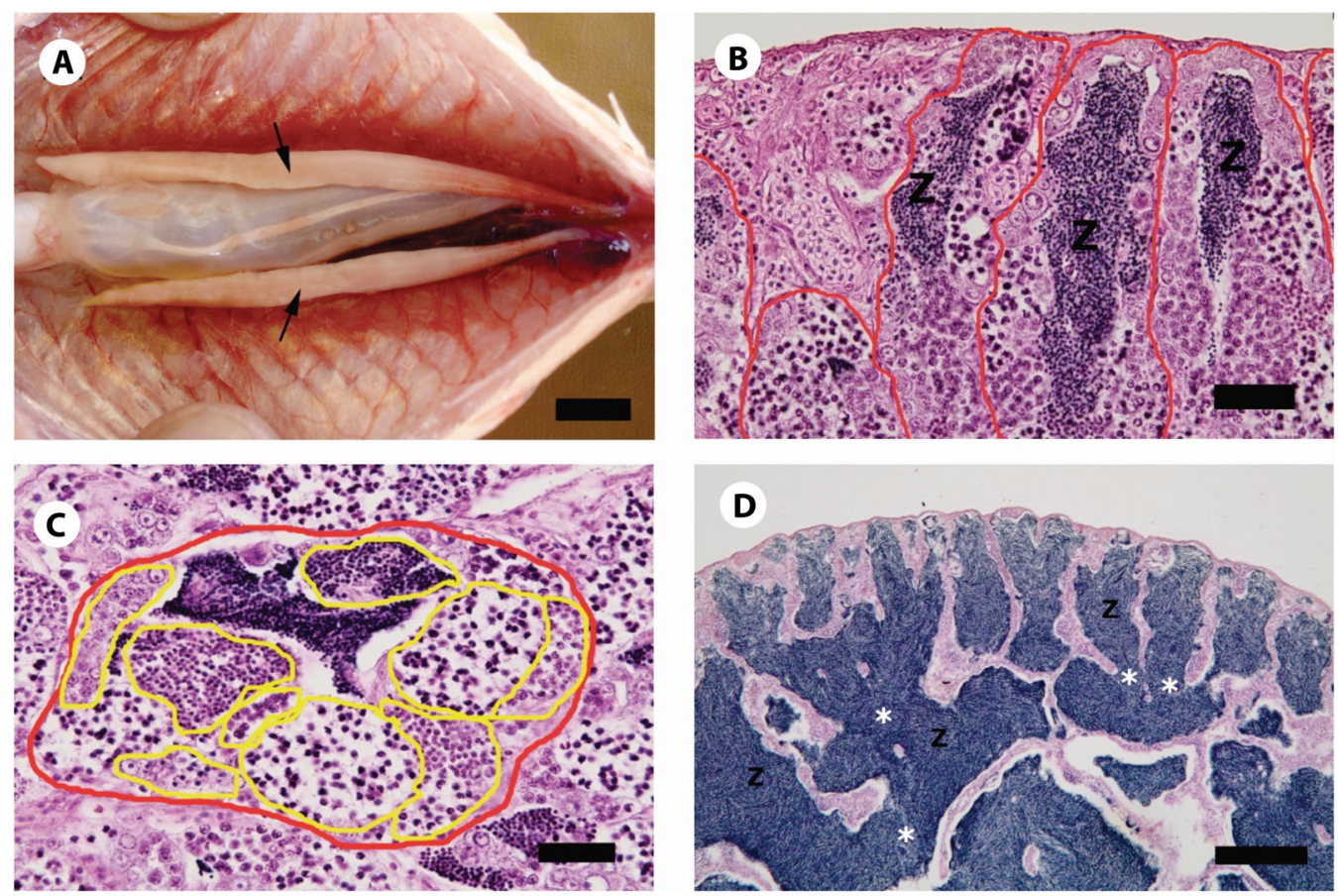

Fig. 4. Mature testis of Anostomidae fishes. A. Macroscopic view of L. piau testis. B. Seminiferous tubules (red marking) in the testis of S. knerii. HE. C. Spermatogenic cells' cysts (yellow marking) in the testis of L. taeniatus. HE. D. Anastomosing tubular testis of S. knerii. HE. Arrows, Testis; Z, Spermatozoas; Black asterisks, Cysts; White asterisks, Anastomosis. Scale bars: A, $4.5 \mathrm{~cm}$; B, $40 \mu \mathrm{m} ; \mathrm{C}, 30 \mu \mathrm{m} ; \mathrm{D}, 200 \mu \mathrm{m}$.

Species that have these characteristics can be considered taken by the author as generalists, while species with largest reserves in the eggs or larvae, can be considered as specialist (Balon, 1975). Although the diameter of the oocytes usually could be related to the reproductive strategy of fish, having the migratory fish oocytes diameters smaller than those of sedentary reproductive strategy (Sato, Fenerechi-Verani, Nuñer, Godinho, \& Verani, 2003), in the present study, the vitellogenic oocytes of the Anostomidae species showed no significant differences, even when we compared sedentary species such as $S$. knerii with migratory species as L. obtusidens.

The vitellogenic oocytes of the analyzed species are grayish, which is a characteristic of the species belonging to the families Anostomidae and Prochilodontidae (Borçato, Bazzoli, \& Sato, 2004; Arantes, Batista dos Santos, Rizzo,
Sato, \& Bazzoli, 2011). The similarity in the color of the oocytes of the species studied is probably due to the fact that they exhibit the same trend of diet, i.e. herbivory (Alvim \& Peret, 2004). Pigments such as astaxanthin, lutein, taraxanthin, and other carotenoids on the yellow/orange yolk coloration have been largely studied in species feed on Krill copepods from temperate waters (Goodwin, 1986; Svensson, Blount, Forsgren, \& Tamudsen, 2010). On the other hand, there are no conclusive studies on neotropical fish species about the origin, composition, and function of the carotenoids on the yolk. Vitellogenic oocytes color varies in teleost amongst the species depending on diet and it is important for offspring identification and selection of healthy females (Blount \& Houston, 2000; Lubzens, Young, Bobe, \& Cerdá, 2010). Little is known about the phylogenetic importance of the yolk color, since 
it has been analyzed mainly between wide vertebrate groups (Lubzens, Lissauer, LeavaviSivan, Avarre, \& Sammar, 2003). Hence, the yolk color can has a role in sexual selection, parental care and feeding behaviors (Blount \& Houston, 2000).

The morphology of the cortical alveoli is an important parameter in fish grouping (Belova, 2008). In this study, we observed cortical alveoli formed by large vesicles in S. knerii and small vesicles in the Leporinus species and in $L$. vittatus. In teleosts, the cortical alveoli content is released into the perivitelline space, at the moment of fertilization, blocking polyspermy and contributing to chorion hardening (Hart, 1990). In this study, we detected in Leporinus, L. vittatus and $S$. knerii, cortical alveoli, neutral glycoproteins and glyco-conjugated carboxylic acids, suggesting that these species may have a similar polyspermy blocking mechanism. This also was corroborated by Bazzoli and Godinho (1994) who studied the morphology and content of the cortical alveoli of 102 species of neotropical fresh water teleosts, who concluded that species of the same family presented cortical alveoli with the same histochemical content and a similar mechanism for blocking polyspermy. Studies using phylogenetic analysis showed that the cortical alveoli morphology is an important parameter amongst the fish families Myctophidae (Myctophiformes), Melamphaidae (Stephanoberyciformes), Bathylagidae and Platytroctidae (Osmeriformes) (Belova, 2008).

The thickness and structure of the zona pellucid depend on the species and reflect adaptations to different ecological conditions (Fausto et al., 2004). In our study, the pellucid zone of the vitellogenic oocytes showed two layers of neutral glycoproteins in all species, which is a common content of pellucid zone of vertebrates (Lubzens et al., 2010). In teleosts, the external layer of the pellucid zone is responsible for the interactions between the egg and the environment (Rizzo et al., 2002). The neutral glycoproteins of the pellucid zone of fish have bactericidal properties and are responsible for the external layer hardening after the release of the oocyte into the environment (Hart, 1990; Lubzens et al., 2010). The thickness of the pellucid zone is also related to the spawning site and may influence adaptations to different ecological conditions (Riehl, 1996; Santos et al., 2006). Species with adhesive eggs tend to have a lower GSI and a thicker pellucid zone in comparison to the species with free eggs (Sato et al., 2003; Melo et al., 2011). In this study, $S$. knerii, whose eggs are adhesive (Rizzo et al., 2002) presented lower GSI and thicker pellucid zone than Leporinus species, whose eggs are free (Rizzo et al., 2002). Leporellus vittatus showed a similar GSI and pellucid zone of the vitellogenic oocytes to that of $L$. piau, L. obtusidens and L. taeniatus which also have free eggs.

The follicular cells of the vitellogenic oocytes of $S$. knerii were higher than those of the Leporinus and L. vittatus, probably due to their eggs adhesiveness. This assumption is reinforced by ultrastructure studies showing, in species with adhesive eggs, follicular cells with a large amount of organelles that synthesize mucosubstances that are transferred to the pellucid zone for a strong adhesiveness of the eggs to the substratum (Andrade, Bazzoli, Rizzo, \& Sato, 2001; Rizzo et al., 2002; Santos et al., 2006). In vitellogenic oocytes of $S$. knerii, cubic follicular cells in the animal pole and prismatic ones on the vegetative pole were observed; similar to what has been registered for Cichlidae (Normando et al., 2009; Martins et al., 2011). The cubic cells synthesize proteins which are important for the micropyle region whereas prismatic cells are involved in the secretion of substances related to the eggs adhesiveness (Rizzo et al., 2002). On another hand, the squamous shape of the follicular cells in the vitelogenic oocytes, generally are related those fish which has free eggs (Sato et al., 2003), as Leporinus and L. vittatus of this study.

The morphologic characteristics of the testis showed a similar pattern to that of the majority of neotropical Charciformes, that have external fertilization, without possessing accessory structures in their gonads (Gonçalves, 
Bazzoli, \& Brito, 2006; Carvalho, Paschoalini, Santos, Rizzo, \& Bazzoli, 2009; Arantes et al., 2011; Martins et al., 2011). The species studied in our work presented spermatogonia throughout the length of the testis, which places them in the unrestricted spermatogonial type according to Grier (1981); a testicular organization that allows a potential germinative cell production (Schulz \& Miura, 2002). In the analyzed species, the seminiferous tubules were connected and characterize the testis as of anastomosing tubular type, a plesiomorphic morphological character present in bonefish (Parenti \& Grier, 2004). In testis of this kind, the seminiferous tubules form anastomosis throughout the gonad, contrary to the neoteleostei which form anastomosis only in the seminiferous tubules located in the central region of the testis (Parenti \& Grier, 2004). The main morphology characteristics here described, also has been reported for other Characidae (Grier, Linton, Leatherland, \& deVlaming, 1980; Martins et al., 2011), reinforcing the fact that the testicular morphology is an important parameter in phylogenetic studies (Parenti \& Grier 2004).

This study showed the phenotypical differences in the vitellogenic oocytes of Anostomidae fishes which probably occur by a phylogenetic closeness, and confirmed the taxonomic position of $S$. knerii as a different genus, in relation to Leporinus species and $L$. vittatus. Despite being placed in a different genus, the characteristics of the vitellogenic oocytes of L. vittatus were similar to those found in the Leporinus species.

\section{ACKNOWLEDGMENTS}

We thank the partnership with the Companhia Energética de Minas Gerais, Centro Integrado de Recursos Pesqueiros e Aquicultura de Três Marias (CODEVASF) and the CAPES, FAPEMIG and CNPq for their financial support.

\section{RESUMEN}

Morfología comparativa de las gónadas de seis especies de peces de la familia Anostomidae (Characiformes: Anostomidae). Teniendo en cuenta que la morfología de las gónadas es un parámetro importante para la comprensión de la biología de la reproducción, las relaciones filogenéticas y estudios sistemáticos, el objetivo principal de este estudio fue realizar un análisis comparativo de la morfología de ovarios maduros y testículos en seis especies de peces de la familia Anostomidae. Un total de 212 especímenes, con las gónadas en maduración, fueron capturados en el río São Francisco, área de embalse de Três Marias, en el sureste de Brasil, entre agosto 2008 y diciembre 2010. Las seis especies analizadas mostraron ovarios maduros de un color grisáceo. En los ovocitos vitelogénicos (VO), los alvéolos corticales (CA) están compuestos por pequeñas vesículas en todas las especies de Leporinus, pero en Leporellus vittatus y Schizodon knerii los CA son grandes vesículas. Los CA de todas las especies mostraron, no obstante, un contenido histoquímico similar. La zona pelucida se compone de dos capas en todas las especies, pero es más gruesa en $S$. knerii $(11.5 \pm$ $1.8 \mu \mathrm{m})$ que en L. vittatus $(9.0 \pm 0.8 \mu \mathrm{m})$ y las especies de Leporinus $(3.5 \pm 0.6-8.7 \pm 0.9 \mu \mathrm{m})$. Las células foliculares de los VO son, cúbico y prismática en polos animales y vegetativos de $S$. knerii $(22.3 \pm 3.2$ y $61.1 \pm 9.6 \mu \mathrm{m})$, respectivamente, y escamosas en las otras especies (1.3 \pm $0.3-1.6 \pm 0.3 \mu \mathrm{m})$. Las hembras de $S$. knerii y los machos de $L$. vittatus mostraron menor GSI que las otras especies evaluadas. Todas las especies presentan una morfología testicular similar a la mayoría de los Characiformes neotropicales, los cuales poseen testículos espermatogonias sin restricciones y organización tubular anastomosis de los túbulos seminíferos. Las diferencias fenotípicas en los VO entre las especies de Anostomidae confirman la posición taxonómica de $S$. knerii como género diferente en relación a Leporinus y L. vittatus. A pesar de ser colocados en diferentes géneros, las características de los ovocitos vitelogénicos de $L$. vittatus son similares a los encontrados en los Leporinus estudiados.

Palabras clave: ovarios, testículos, células foliculares, peces de agua dulce, histología.

\section{REFERENCES}

Alvim, M. C. C., \& Peret, A. C. (2004). Food resources sustaining the fish fauna in a section of the upper São Francisco river in Três Marias, MG, Brazil. Brazilian Journal of Biology, 64(2), 195-202.

Andersen, M. L., D’Almeida, V., Ko, G. M., Martins, P. J. F., Magalhaães, L. E., \& Tufik, S. (2008). Principios 
Éticos e Práticos do Uso de Animais de Experimentação. São Paulo: Unifesp.

Andrade, R. F., Bazzoli, N., Rizzo, E., \& Sato, Y. (2001) Continuous gametogenesis in the neotropical freshwater teleost, Bryconops affinis (Pisces: Characidae). Tissue and Cell, 35(5), 524-532.

Arantes, F. P., Batista dos Santos, H., Rizzo, E., Sato, Y., \& Bazzoli, N. (2011). Collapse of the reproductive process of two migratory fish (Prochilodus argenteus and Prochilodus costatus) in the Três Marias Reservoir, São Francisco River, Brazil. Journal of Applied Ichthyology, 27(3), 847-853. doi: 10.1111/j.1439-0426.2010.01583.x

Balon, E. K. (1975). Reproductive guilds of fishes: A proposal and definition. Journal of the Fisheries Research Board of Canada, 32(6), 821-864.

Balon, E. K. (1990). Epigenesis and an epigeneticist: the development of some alternative concepts on the early ontogeny and evolution of fishes. Guelph Ichthyology Reviews, 1, 1-48.

Bazzoli, N. (2003). Parâmetros reprodutivos de peixes de interesse comercial na região de Pirapora. In H. P. Godinho \& A. L. Godinho (Eds.), Águas, peixes e pescadores do São Francisco das Minas Gerais (pp. 291-306). Belo Horizonte: Editora PUC Minas.

Bazzoli, N., \& Godinho, H. P. (1994). Cortical alveoli in oocytes of freshwater neotropical teleost fish. Italian Journal of Zoology, 61(4), 301-308.

Belova, G. V. (2008). Oocyte morphology of several mesopelagic fishes in connection with their taxonomic status and habitat conditions. Russian Journal of Marine Biology, 34(2), 110-117.

Blount, J. D., \& Houston, D. C. (2000). Why egg yolk is yellow. Tree, 15, 47-49.

Borçato, F. L., Bazzoli, N., \& Sato, Y. (2004). Embriogênese e ontogênese larval do piau-gordura Leporinus piau (Characiformes, Anostomidae) após desova induzida. Zoologia, 1, 117-122.

Carvalho, P. A., Paschoalini, A. L., Santos, G. B., Rizzo, E., \& Bazzoli, N. (2009). Reproductive Biology of Astyanax fasciatus (Pisces: Characiformes) in a reservoir in southeastern Brazil. Journal of Applied Ichthyology, 25, 306-313.

Fausto, M. A., Picchietti, S., Tadei, A. R., Zini, C., Scapigliati, G., Mazzini, M., \& Abelli, L. (2004). Formation of the egg envelope of a teleost, Dicentrarchus labrax (L.): immunochemical and cytochemical detection of multiple components. Anatomy and Embryology, 208, 43-53.

Fishelson, L., \& Gon, O. (2008). Comparative oogenesis in cardinal fishes (Apogonidae, Perciformes), with special focus on the adaptative structures of the egg envelopes. Environmental Biology of Fishes, 81(4), 397-414.

Garavello, J. C., \& Britski, H. A. (2003). Anostomidae. In R. E. Reis, S. O. Kullander, \& C. J. Ferraris Jr, (Eds.), Check list of the freshwater fishes of South and Central America (pp 71-84). Porto Alegre: EDIPUCRS.

Godinho, A. L., Lamas, I. R., \& Godinho, H. P. (2010). Reproductive ecology of Brazilian freshwater fishes. Environmental Biology of Fishes, 87, 143-162.

Gonçalves, T. L., Bazzoli, N., \& Brito, M. F. G. (2006). Gametogenesis and reproduction of the matrinxã Brycon orthotaenia (Günther, 1864) (Pisces: Characidae) in the São Francisco River, Minas Gerais, Brazil. Brazilian Journal of Biology, 66(2A), 513-522.

Goodwin, T. W. (1986). Metabolism, nutrition and function of carotenoids. Annual Review of Nutrition, 6, 273-297.

Grier, H. J. (1981). Cellular organization of the testis and spermatogenesis in fishes. American Zoologist, 21(2), 345-357.

Grier, H. J., Linton, J. R., Leatherland, J. F., \& deVlaming, V. L. (1980). Structural evidence for two difference testicular types in teleost fishes. American Journal of Anatomy, 159, 331-345.

Hart, N. H. (1990). Fertilization in teleost fishes: Mechanism of sperm-egg interactions. International Review of Cytology, 121, 1-66.

Kolm, N., \& Ahnesjö, I. (2005). Do egg size and parental care coenvolve in fishes? Journal of Fish Biology, 66, 1499-1515.

Lubzens, E., Lissauer, L., Leavavi-Sivan, B., Avarre, J. C., \& Sammar, M. (2003). Carotenoid and retinoid transport to fish oocytes and eggs: What is the role of retinol binding protein? Molecular Aspects of Medicine, 24(6), 441-457.

Lubzens, E., Young, G., Bobe, J., \& Cerdà, J. (2010). Oogenesis in teleosts: How fish eggs are formed. General Comparative Endocrinology, 165, 367-389.

Martins, Y. S., Arantes, F. P., Sato, Y., Santos, J. E., Rizzo, E., \& Bazzoli, N. (2011). Comparative analysis of gonadal morphology in six fish species of the Incertae Sedis genera in Characidae of occurrence in the São Francisco River Basin, Brazil. Acta Zoologica-Stockholm, 93, 48-56. doi: 10.1111/j.1463-6395.2010.00478.x

Melo, R. M. C., Arantes, F. P., Sato, Y., Santos, J. E., Rizzo, E., \& Bazzoli, N. (2011). Comparative morphology of the gonadal structure related to reproductive strategies in six species of neotropical catfishes (Teleostei: Siluriformes). Journal of Morphology, 272, 525-535. doi: 10.1002/jmor.10931 
Nelson, J. S. (2006). Fishes of the World. NewYork: John Wiley \& Sons.

Normando, F. T., Arantes, F. P., Luz, R. K., Thomé, R. G., Rizzo, E., Sato, Y., \& Bazzoli, N. (2009). Reproduction and fecundity of tucunaré, Cichla kelberi (Perciformes: Cichlidae), an exotic species in Três Marias reservoir, southeastern Brazil. Journal of Applied Ichthyology, 25, 299-305.

Parenti, L. R., \& Grier, H. J. (2004). Evolution and phylogeny of gonad morphology in bony fishes. Integrative and Comparative Biology, 44(5), 333-348.

Patiño, R., \& Sullivan, C. V. (2002). Ovarian follicle growth, maturation and ovulation in teleost fishes. Fish Physiology and Biochemistry, 26, 57-70.

Pearse, A. G. E. (1985). Histochemistry: Theoretical and Applied. London: Churchill Livingstone.

Reis, R. E., Kullander, S. O., \& Ferraris Jr, C. J. (2003). Checklist of the Freshwater Fishes of South and Central America. Porto Alegre: EDIPUCRS.

Riehl, R. (1996). The ecological significance of the egg envelope in teleosts with special reference to limnic species. Limnologica, 26, 183-189.
Rizzo, E., Sato, Y., Barreto, B. P., \& Godinho, H. P. (2002). Adhesiveness and surface patterns of eggs in neotropical freshwater teleosts. Journal of Fish Biology, 61(3), 615-632.

Santos, J. E., Padilha, G. E. V., Bomcompagni Jr, O., Santos, G. B., Rizzo, E., \& Bazzoli, N. (2006). Ovarian follicle gownth in the catfish Iheringichthys labrosus (Siluriformes: Pimelodidae). Tissue and Cell, 38, 303-310.

Sato, Y., Fenerechi-Verani, N., Nuñer, A. P. O., Godinho, H. P., \& Verani, J. R. (2003). Padrões reprodutivos de peixes da bacia do São Francisco. In H. P. Godinho \& A. L. Godinho (Eds.), Águas, peixes e pescadores do São Francisco das Minas Gerais (pp. 229-274). Belo Horizonte: Editora PUC Minas.

Schulz, R. W., \& Miura, T. (2002). Spermatogenesis and its endocrine regulation. Fish Physiology and Biochemistry, 26(1), 43-56.

Svensson, P. A., Blount, J. D., Forsgren, E., \& Tamudsen, T. (2010). Female ornamentation and egg carotenoids of six sympatrics gobies. Journal of Fish Biology, 75, 2777-2787. 
